Субтропическое и декоративное садоводство (66)

в субтропиках России // Садоводство и виноградарство. - 2015. - № 1. - С. 33-35. ISSN: 0235-2591.

7. Смагин Н.Е., Абильфазова Ю.С. Характеристика сортов персика для импортозамещения // Вестник российской селькохозяйственной науки. - 2016. - № 5. - С. 57-59. - ISSN: 2500-2082.

8. Смыков В.К. Помология, Т. ІІІ. - Киев: Урожай, 1997. - 280 с.

9. Чендлер У. Плодовый сад. Листопадные плодовые культуры. - М: Сельхозгиз, 1960. $-620 \mathrm{c}$.

\title{
RESULTS OF USING PEACH GENE POOL IN THE RUSSIAN HUMID SUBTROPICS
}

\author{
Smagin N. Ye., Tsymbalova A. A. \\ Federal State Budgetary Scientific Institution \\ "Russian Research Institute of Floriculture and Subtropical Crops", \\ c.Sochi,_Russia,e-mail:n_cimb@mail.ru
}

The paper presents the results of studying 58 peach cultivar-samples in the collection of the Russian Research Institute of Floriculture and Subtropical Crops for 12 years (2007-2018). The existing peach assortment was updated due to 10 selected perspective cultivars and clones: cultivars - 'Springgold', 'Medin Red', 'Earley Blow', 'Summerset', 'Comanche', 'Fayette' and clones - 'Ranniy Collins' ('Nicolai I'), 'Rannyaya zarya', 'Krasnaya zarya' and 'Larisa'. In 2018, clone 'Larisa' was included into the State Register of Selection Achievements of the Russian Federation. The new presented cultivars and clones provide a fresh fruit conveyor for 2.5 months, both due to early cultivars ('Springgold') and later ('Fayette'), as well as cultivars and clones whose fruits ripen between the main industrial cultivars: 'Favorita Morettini', 'Collins', 'Redhaven', 'Veteran'. The allocated promising cultivars and clones are the most productive with high commercial qualities of fruit, not very demanding for cold in winter and heat in spring, which are limiting factors for the successful peach cultivation in the Russian subtropics. The method of estimating the lack of cold for peach in the winter is specified.

Key words: peach, subtropics, cultivars, clones, productivity, conveyor of fresh fruits.

doi: $10.31360 / 2225-3068-2018-66-86-90$

\section{НЕКОТОРЫЕ ВИДЫ \\ ALLIUM ПОДРОДА MELANOCROMМYUM В УСЛОВИЯХ ИСКУССТВЕННОГО ФИТОЦЕНОЗА}

Уралов А. И.

Институт ботаники Академии наук Республики Узбекистан,

2. Ташкент, Республика Узбекистан, е-mail: uralov.85@mail.ru

Проведённое в 2016 г. в ботаническом саду г. Ташкента обследование выявило представителей рода Allium. Все обнаруженные виды - луковичные геофиты с эфемероидным типом развития - произрастают на мягких 
Глава 2. Интродукция и сортоизучение

почвах (A. suworowii, A. cristophii, A. stipitatum и A. giganteum). Один вид сорничает (A. suworowii). Большинство видов сохраняются преимущественно в полутенистых и тенистых местах. Это можно объяснить тем, что растения при этом избегают конкуренции со злостными сорными растениями. Являясь ранневесенними эфемероидами, эти виды успевают до развития листьев на древесных растениях накопить достаточный запас питательных веществ в луковице.

Ключевые слова: Allium, интродукция, искусственный фитоценоз, генеративный побег, вегетативное размножение.

В Ботаническом саду г. Ташкента (ныне Ботанический сад им. академика Ф. Н. Русанова при институте ботаники Академии Наук Республики Узбекистан) интродукция среднеазиатских видов Allium началась одновременно с созданием самого сада в 50-е годы прошлого столетия. Трудами 3. Н. Филимоновой была собрана богатейшая коллекция, насчитывающая более 100 видов [4]. К сожалению, с уходом 3. Н. Филимоновой эта коллекция была утеряна. Позднее на экспозиции «Флора и растительность Средней Азии» интродукционное изучение прошли около 50 видов Allium [3].

За время интродукционного изучения некоторые виды расселились по территории сада, рассматриваемого как культурфитоценоз, где и произрастают по настоящее время без какого-либо ухода. Проведённое в 2016 г. обследование выявило следующие виды (табл. 1), находящиеся в составе искусственного фитоценоза. Систематическое положение приводилось по Ф. У. Хасанову [5], распространение - по «Флоре СССР» [1] и «Флоре Узбекистана» [2].

Allium altissimum Regel. Подрод Melanocrommyum, секция Megaloprason. Естественно произрастает на мягких склонах в среднем поясе гор. В Узбекистане встречается в Жиззакской (Нуратинский хр.) области. В саду обнаружен в 2 местах - на солнечном и в полутени. Наибольшая популяция достигает $10 \mathrm{~m}^{2}$. Вегетативно размножается, в компактном клоне насчитывается до 8-15 растений. Генеративный побег несёт (3)-5-8 листьев. Число цветков до 300. Хорошо плодоносит.

A. cristophii Trautv. Подрод Melanocrommyum, секция Kaloprason, подсекция Kaloprason. Естественно произрастает на мягких склонах гор, преимущественно в нижнем поясе. Эндем горной Туркмении. Луковичный геофит с эфемероидным ритмом развития. В саду обнаружены 3 немногочисленные группы растений в тени под кустарниками и деревьями. Генеративный побег несёт 2-10 листьев. В соцветии до 200 цветков. Все цветущие растения плодоносят. Вегетативно не размножается.

A. giganteum Regel. Подрод Melanocrommyum, секция Cотрасtoprason, подсекция Erectotepala. Естественно произрастает на мягких 
склонах в нижнем поясе гор. В Узбекистане встречается в Сурхандарьинской (Кухитангтау хр.) области. В саду обнаружен в 3 местах: на солнечном, в полутени и тени. Наибольшая популяция 24 м². Вегетативно размножается - в компактном клоне до 8 растений. Генеративный побег несёт по 4-6 листьев. Число цветков до 800. Плодоносит хорошо.

A. stipitatum Regel. Подрод Melanocrommyum, секция Megaloprason, подсекция Elatae. Естественно произрастает на мягких склонах в среднем поясе гор. В Узбекистане встречается в Ташкентской (р. Ангрен), Самаркандской (Зарафшанский хр.) и Жиззакской (Нуратинский хр.) областях. В саду распространён повсеместно, но предпочитает полутень или тень. Самая большая популяция до $1500 \mathrm{~m}^{2}$. Вегетативно размножается, в компактном клоне насчитывается до 15-20 растений. Генеративный побег несёт (4)-5-7 листьев. Число цветков до 300. Хорошо плодоносит.

A. suworowii Regel. Подрод Melanocrommyum, секция Acmopetala, подсекция Spiralotunicata. Естественно произрастает на мягких почвах в предгорьях, преимущественно как сорное растение в оазисах. В Узбекистане встречается в Ташкентской, Ферганской и Самаркандской областях. В саду обнаружено 2 местопроизрастания - в тени и полутени.

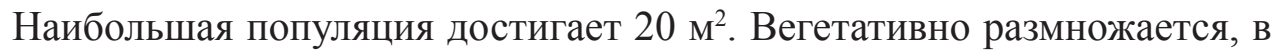
компактном клоне насчитывается не более 8 растений. Цветёт обильно. Генеративный побег несёт 2-6 листьев. В соцветии до 200 цветков. Все цветущие растения плодоносят.

A. protensum Wendelbo. Подрод Melanocrommyum, секция Kaloprason, подсекция Kaloprason. Естественно произрастает на щебнистых почвах нижнего пояса гор и песках. В Узбекистане встречается в Жиззакской, Самаркандской, Бухарской, Навоинской областях. В саду обнаружен в одном

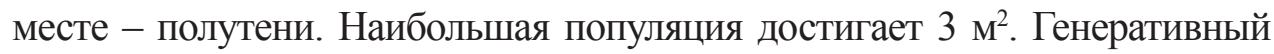
побег несёт (2)-4-6 листьев. Хорошо плодоносит. В соцветии до 200 цветков. Все генеративные растения плодоносят. Вегетативно не размножается.

A. rosenbachianum Regel. Подрод Melanocrommyum, секция Megaloprason, подсекция-Megaloprason. Естественно произрастает на мелкозёмных площадках в среднем поясе гор, в тени скал и деревьев. В саду растения произрастают в тени под кустарниками и деревьями. Генеративный побег несёт 2-5 листьев. В соцветии до 100 цветков. Все генеративные растения плодоносят. Вегетативно размножается.

A. trautvetterianum Regel. Подрод Melanocrommyum, секция Compactoprason, подсекция Erectotepala. Естественно произрастает на выходах пёстроцветных пород. В саду растения произрастают в тени под кустарниками и деревьями. Генеративный побег несёт 3-5 листьев. 
Глава 2. Интродукция и сортоизучение

В соцветии до 200 цветков. Все генеративные растения плодоносят. Вегетативно размножается.

A. aroides Popov \& Vved. Подрод Melanocrommyum, секция Aroidea. Естественно произрастает на каменистых и мелкозёмных склонах в нижнем поясе гор. В Узбекистане встречается в Самаркандской области (Зарафшанский хр.). Эндем. В саду растения произрастают на солнечном участке. Генеративный побег несёт 2-3 листьев. В соцветии до 100 цветков. Все генеративные растения плодоносят. Вегетативно размножается.

Таблийа 1

Виды, произрастающие в Ташкентском ботаническом саду

\begin{tabular}{|c|c|c|c|c|c|c|}
\hline Виды & 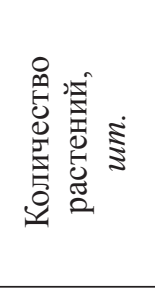 & 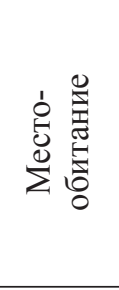 & 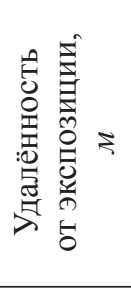 & 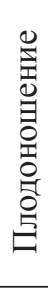 & 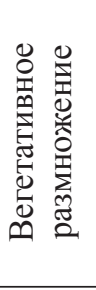 & 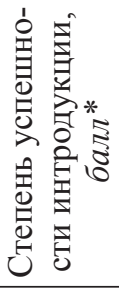 \\
\hline Allium altissimum Regel & Св. 100 & $\Pi$ & Св. 100 & + & + & 3 \\
\hline A. aroides Popov \& Vved & Св. 100 & $\mathrm{C}, \Pi$ & Св. 100 & + & + & 3 \\
\hline A. trautvetterianum Regel & Св. 100 & $\mathrm{~T}$ & До 50 & + & + & 3 \\
\hline A. cristophii Trautv. & Св. 100 & $\Pi$ & До 50 & + & & 3 \\
\hline A. giganteum Regel & Св. 100 & $\Pi, \mathrm{T}$ & До 50 & + & + & 3 \\
\hline A. protensum Wendelbo & $\sim 50$ & $\mathrm{~T}$ & До 10 & + & & 3 \\
\hline A. rosenbachianum Regel & $\sim 50$ & $\mathrm{~T}$ & До 5 & + & + & 3 \\
\hline A. stipitatum Regel & Св. 1000 & $\mathrm{C}, \Pi, \mathrm{T}$ & Св. 100 & + & + & 3 \\
\hline A. suworowii Regel & Св. 500 & $\Pi$ & Св. 100 & + & + & 3 \\
\hline
\end{tabular}

Примечание: местообитание по степени освещённости:

$$
\begin{aligned}
& \text { С-открытое (солнечное); } \\
& \text { П-полутень; } \\
& \text { Т-тень. }
\end{aligned}
$$

* - степень успешности интродукции приведена по А. О. Титовой [3]:

3 балла - высокая - растения цветут и плодоносят;

2 балла - средняя - плодоношение периодическое;

1 балл - низкая - растения не плодоносят

Подавляющее большинство обнаруженных нами видов, по данным О. А. Титовой [3], имеют высокую степень успешности интродукции (регулярно плодоносят). Наибольшую способность к расселению проявили виды Allium, многие их которых вышли далеко за пределы экспозиций, 
предпочитая полутень или даже тень, где отсутствуют злостные сорные растения (Allium altissimum, A. stipitatum, A. suworowii).

Таким образом, все обнаруженные виды - луковичные геофиты с эфемероидным типом развития. Произрастают на мягких почвах (A. suworowii, A. cristophii, A. stipitatum и A. giganteum). Один вид сорничает (A. suworowii). Преимущественное сохранение большинства видов в полутени и тенистых местах можно объяснить тем, что растения при этом избегают конкуренции со злостными сорными растениями. Являясь ранневесенними эфемероидами, эти виды успевают до развития листьев на древесных растениях накопить достаточный запас питательных веществ в луковице.

\title{
Библиографический список
}

1. Введенский А.И. Allium L. // Флора СССР. - Л.: Изд-во АН СССР, 1935. - Т. 4. - С. 112-280.

2. Введенский А.И. Allium L. - Лук // Флора Узбекистана. - Ташкент: Изд-во АН РУз, 1941. - Т. 1. - С. 426-466.

3. Титова О.А. Определение успешности интродукции однодольных растений Средней Азии // Интродукция и акклиматизация растений в аридных условиях: отчёт о выполнении НИР: (заключительный). - Ташкент: НПЦ «Ботаника» АН РУз, 2007. - С. 64-68. 4. Филимонова 3.Н. К онтогенезу и морфологии некоторых видов рода Allium L.: автореф. дис. ... канд. биол. наук. - Ташкент, 1958. - 16 с.

5. Хасанов Ф. О. Род Allium L. во флоре Средней Азии: автореф. дис. ... д-ра биол. наук. - Ташкент, 2008. -35 c.

\section{SOME SPECIES \\ OF ALLIUM SUBG. MELANOCROMMYUM IN CONDITIONS OF ARTIFICIAL PHYTOCOENOSIS}

\author{
Uralov A. I. \\ Institute of Botany of the Science \\ Academy of the Republic of Uzbekistan, \\ c. Tashkent, the Republic of Uzbekistan,e-mail: uralov.85@mail.ru
}

The survey conducted in the Botanical Garden of Tashkent city in 2016 revealed some representatives of the genus Allium. All species found are bulbous geophytes with an ephemeric type of development. They grow on soft soils (Allium suworowii, A. cristophii, A. stipitatum and A. giganteum). One species is weeded (A. suworowii). The predominant preservation of most species in the penumbra and shady places can be explained by the fact that plants at the same time avoid competition with malicious weeds. Being early-spring ephemeroids, these species manage to accumulate a sufficient supply of nutrients in a bulb prior to the development of leaves on woody plants.

Key words: Allium, introduction, artificial phytocenosis, generative shoot, vegetative reproduction. 